University of Louisville

ThinkIR: The University of Louisville's Institutional Repository

Electronic Theses and Dissertations

1947

\title{
A study of the synthesis of 4-chlorobutanal.
}

Carl E. Moore 1915-2012

University of Louisville

Follow this and additional works at: https://ir.library.louisville.edu/etd

Part of the Chemistry Commons

\section{Recommended Citation}

Moore, Carl E. 1915-2012, "A study of the synthesis of 4-chlorobutanal." (1947). Electronic Theses and Dissertations. Paper 2059.

https://doi.org/10.18297/etd/2059

This Master's Thesis is brought to you for free and open access by ThinkIR: The University of Louisville's Institutional Repository. It has been accepted for inclusion in Electronic Theses and Dissertations by an authorized administrator of ThinkIR: The University of Louisville's Institutional Repository. This title appears here courtesy of the author, who has retained all other copyrights. For more information, please contact thinkir@louisville.edu. 
UIIVURSITY OF LOUISVILLE

A. STUDY OF THE SYNTHESIS OF 4-CHLOROBUTANAL

\author{
A Dissertation \\ Submitted to the Faoulty \\ Of the Graduate Sohool of the university of Louisville \\ In rertial Fulfillmont of tho \\ Bequiremonts for the Dogroe \\ of rester of seionce
}

Departmont of Chemistry

By

CARL E. yoORE

1947

$75 \% 11$ 


\section{UNIVERSITY}

LIBRARIES

This PDF document is a scanned copy of a paper manuscript housed in the University of Louisville (UofL) Libraries. The quality of this reproduction is greatly dependent upon the condition of the original paper copy. Indistinct print and poor quality illustrations are a direct reflection of the quality of materials that are available for scanning. The UofL Libraries greatly appreciates any better copies that can be made available for replacement scans. 
rimur or rHesis a study if the fypothenis of t-chlarofutanal

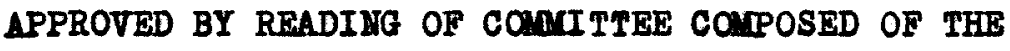
FOLIOIIITE YEWBERS:

J. R. Broderius

J. J. Oppenheimer

C. C. Vernon

MAUE OF DIRECTOR:

M. I. Bowman

DATE: Qunes, 1947 


\section{ACUTOWLEDECENTS}

The writer wishes to express his appreoiation to Dr. Max I. Borman, Assistant Professor of Chemistry, College of Arts and Soiences, University of Louisville, for his counsel and guidance and for his kind cooperation in carrying out the literature searches. Appreoiation is also oxprossed to his wife, Mary Agnes Moore, for her generous contribution of helpful suggestions and critioisms conoerning the preparation of the manusoript. 


\section{CotrE-TS}

Purpose ....................................... 1

History.$\ldots \ldots \ldots \ldots \ldots \ldots \ldots \ldots \ldots \ldots \ldots \ldots \ldots \ldots \ldots \ldots \ldots \ldots \ldots \ldots \ldots \ldots \ldots \ldots$

Theory and Disoussion .............................. 4

A. Stephen Reduetion ...........................4

B. Oxidation Mothods ........................... 5

1. Oxidation by Air .........................6

2. Oxidation by oxygen ........................ 6

3. Oxidation by Hydrogon poroxide ............... 6

4. Oxidation by Dichromato ....................... 9

synthesis ..................................... 11

A. Stephen keduction of Nitrilos ................... 11

1. Preparation of Constant Boiling Hydrobromio Acid .. 11

2. Synthesis of Irimethylenechlorobromide ........... Il

3. Proparation of Anhydrous Stannous Chloride ........ 12

4. Preparation of Gamma-Chlorobutyronitrile ......... 13

5. Reduction of Aldimine Stanniohloride ........... 13

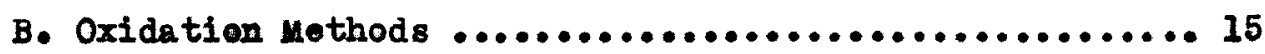

1. Freparation of Tetramothylonoohlorhydrin ........ 15

2. Oxidation by Means of pure Oxygon ............... 16

3. Oxidation by Moans of Copper Bronze Catalyst ...... 16

4. Oxidation with Hydrogen Peroxide ............... 16

5. Tables $\ldots \ldots \ldots \ldots \ldots \ldots \ldots \ldots \ldots \ldots \ldots \ldots \ldots \ldots \ldots \ldots \ldots \ldots \ldots \ldots . . \ldots 18$

summary .......................................... 23

Litorature Cited .................................. 24 


\section{PUPP085}

The original purpese of this researoh was to prepare gamma-ohlorobutyraldehydo in yields sufficiont for uso in further synthesis. Froparatire diffieulties, howoror, made it nocessary to alter this purpose to include a more general study of aldehyde synthesis in order to acoomplish a satisfactory proparation of the compound. Thus the final intent of this undertaking was to oraluate existing synthetio methods in reapect to the compound desired and to investigate now mothods of aldohyde synthesis. 
HISTORY OF 4-CHLOROBUTANAL

4-chlorobutanal was first roported in 1942 by paul (10). who repared the compound from totrahydrofurfuryl alcohol, which has rocently become oasily available. Rocent researchos (9) have established that totrahydrofurfuryl alcohols may bo prepared with good yields by starting with furfural, a material obtainod as a by-produot in the coreal industry. The ring of tetruhydrofurfuryl alcohol was oponed by reacting with aovtylohloride, yielding 5-chloro-1,2-pentanediacotato, which was hydrolyzed by barium hydrozide to 5,chloro-1,2-pentanediol:

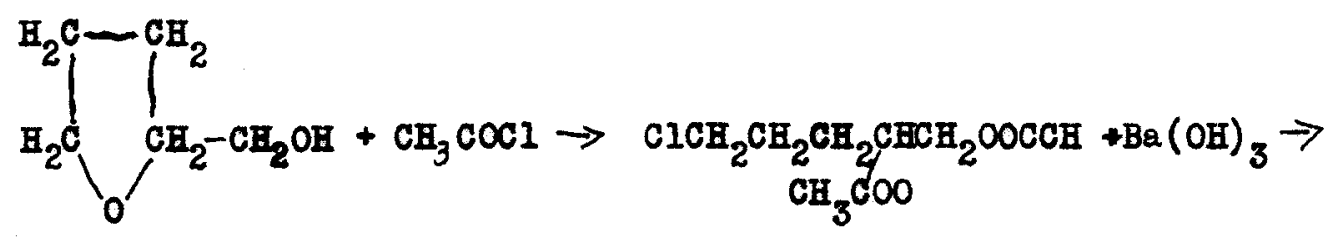
$\mathrm{ClCH}_{2} \mathrm{CH}_{2} \mathrm{CH}_{2} \mathrm{CHOHCH}_{2} \mathrm{OH}+\mathrm{Ba}(\Lambda 0)_{2}$

The 5-chloro-1,2-pentanediol was oxidized with lead tetracetato to give gamma-ohlorobutyraldohyde:

$$
\mathrm{ClCH}_{2} \mathrm{CH}_{2} \mathrm{CH}_{2} \mathrm{CHOHCH} / 2 \mathrm{OH}+\mathrm{Pb}(\mathrm{Ac})_{4} \rightarrow \mathrm{ClCH}_{2} \mathrm{CH}_{2} \mathrm{CH}_{2} \mathrm{CHO}+\mathrm{HCOOH}
$$


Paul also propared the aldehyde by the use of sodium iodate but without adrantage.

The article by Paul reported that 4-chlorobutanal Is a colorless liquid of ponotrating odor (b.p. $50^{\circ} \mathrm{C}-60^{\circ} \mathrm{C}$ at $\left.13 \mathrm{~mm} ; \mathrm{D}_{15}^{8.5} 1.107 ; \mathrm{y}_{\mathrm{D}}^{8.5} 1.44662\right)$. It gave the following derivatives: p-nitrophonylhydrazone, m.p. 110; 2,4-dinitrophonylhydraz one, m.p. 134-135; oximo, m.p. 74.5, easily roarranged by Raney nickel to 4-ohlorobutjramide, m.p. $99^{\circ} \mathrm{C}-100^{\circ} \mathrm{C}$. The aldohyde polymerizes readily under the influence of heat. There was no yiold figure givon, just the statement that the reaction takes place with suitable yiold. 
THEORY AND DISCUSSION

DI SCUSSIOI OF ALDEHYDE METHODS

Stophon Roduotion

of the various aldehyde mothods considered, the Stephen Reduction (11) looked most promising because it is recognized to give oxcellent yields, exoept for a few oompounds in the aromatic series. The basis of this mothod is the conversion of nitrile through the imino-ohloride into the aldohyde with the same number of carbon atoms, the reducing agent being stannous ohloride dissolved in ether saturated with hydrogen ohloride. Gama-ohlorobutyronitrilo was prepared by conventional mothods (Seo Experimental Part.)

$$
\begin{aligned}
& \mathrm{ClCH}_{2} \mathrm{CH}_{2} \mathrm{CH}_{2} \mathrm{CH}+\mathrm{SnCl}_{2} \rightarrow \mathrm{ClCH}_{2} \mathrm{CH}_{2} \mathrm{CH}_{2} \mathrm{CH}^{2} \mathrm{NH} . \mathrm{HCl} \\
& \mathrm{ClCH}_{2} \mathrm{CH}_{2} \mathrm{CH}_{2} \mathrm{CH} \text {. } \mathrm{CH}+\mathrm{HCl}+\mathrm{H}_{2} \mathrm{O} \rightarrow \mathrm{ClCH}_{2} \mathrm{CH}_{2} \mathrm{CH}_{2} \mathrm{CHO}+\mathrm{NH}_{3}
\end{aligned}
$$

The reaction first osrried out according to stophen's original direotions (II) with negative results. It was deoided to attempt the reaction again, using the drastic conditions recommonded by King (6). The attempt was oarried out by keoping the reaction mixture under roflux for 84 hours, with vory little iminoohloride forming. A drop 
of water was added because Thitmore (12) reports that absolutely dry other should not bo used in this reaction. No yield of aldehyde mas obtained. It is of interest to note that a 11 anount of what probably iminochloride 8 formod under the more drastic conditions of the reaction. There is some indication, therefore, that this reaction might be favored by further intensifying the conditions by choosing a higher boiling othor than the othyl other used. Two other nitriles, alphanapthonitrile and o-toluonitrilo, were roported to hare feiled to rospond to the more drastie troatmont. Howerer, other compounds, such as gamapthalimido-alpha-mothylbutyraldehyde and gama-phonoxybutyraldehyde can bo obtained in good yield under the more drastic conditions (6).

\section{Oxidation Methods}

It was considered desirable to abandon the stephen Reduction and to attempt to propare the aldehydo from totramothylonochlorhydrin bocause this compound is now oasily obtainable from tetrahydrofuran (4), which E.I. DuPont De Nemours \& Company is now producing in research quantitios. 


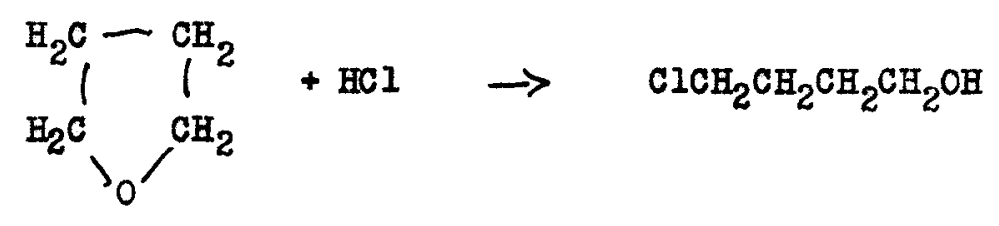

Attempts to oxidize the alcohol directly by means of air and catalyst (16) and pure oxygen and a catalyst were unsuccessful. The mothod using air and a cotalyst failed to work because the tomperature nocessary for this reaction is so high that under the influence of the copper bronze and quinoline, hydrogen, chloride split out, resulting in a recovery of the tetrahydrofuran.

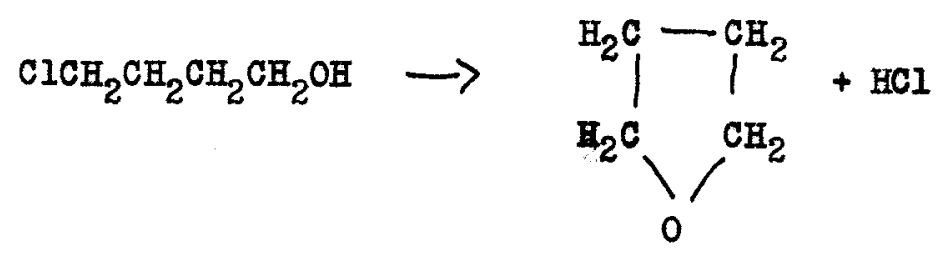

Hydrogen peroxide has long been used suecessfully in oxidation methods in organic chemistry. However, there still appears to bo a great deal to be learned about the chemistry of this useful reagent. A groat step forward in this direction was made by Kharasch $(5,7)$ in his work on the concept of free radicals in solution. Most of this work on the poroxides has dealt with the anomalies of peroxide-produced additions at 
couble bonds. Some oxidations have been explained by the peroxide offect, notably the Cannizzaro Reaction (13), in which benzaldehyde is converted into benzoic acid and benzyl alcohol. The fact that peroxides are formed easily with aldehydes and are readily oxidized to acids is a serious hindrance to this method for aldehyde preparation (14): Some difficultly prepared aldehydes may be obtained by the peroxide oxidation methods. Glyoeraldehyde may bo prepared by moans of peroxide oxidation (15) where other mothods fail. The most successful of the peroxide oxidative methods use a ferrous ion catalyst. The function of this oatalyst is not fully explained. One author postulates an addition product of the hydrogen peroxide and ferrous ion (2). It has not been within the seope of this work to clarify the mechanism of the peroxide oxidation of alcohols to aldehydes.

A study we undertaken to establish the best conditions for the oxidation of tetramethylenoehlorhydrin to gamma-chlorbutyraldohyde aftor the mothod used for proparing glyceraldehyde (2) failed to givo aldohyde in sufficiont amount to permit yield measuroments. It was decided to conduct a series of experiments in which the mole ratios of $\mathrm{Fe}^{+2} / \mathrm{ROH}$ and $\mathrm{H}_{2} \mathrm{O}_{2} / \mathrm{ROH}$ and the temperature were varied and 
the resulting products analyzed for the por cent aldehyde produced. The mole ratios of $\mathrm{Fe}^{+2} / \mathrm{ROH}$ and $\mathrm{H}_{2} \mathrm{O}_{2} / \mathrm{ROH}$ were set at 0.1 and 0.25 respectivoly. The temporature was varied from $10^{\circ}$ to $100^{\circ}$ and the yields determined (see Tablo 1). With the optimum temperature and the alcohol and peroxide ratios constent, the best $\mathrm{F} \cdot \mathrm{ROH}$ ratio was determined (See Table 2).

The above experiment was ropeated, using manganese dioxide to destroy the exoess peroxide. This change resulted in an improved yield. It also demonstrated that the reaction was practically instantanoous. In cases whore no forrous catalyst had been used and a large exoess of ferrous ion added to destroy the peroxide immodiatoly, no change was noted in the yiold. Then no forrous ion was used and a large excess of manganese dioxide added to destroy the hydrogen peroxide, no aldehyde was formed. By seloction of the optimum reaction conditions it was found possible to increase the aldehyde yield to $28 \%$ based on the hydrogen peroxide used.

Glacial acotic acid was next chosen as a likely solront for the perexide oxidation because of its strong solvent properties, oren though certain acids are known to inhibit the broakdown of hydrogen peroxide $(8)$. The reaction was then run in glacial acetic acid, using the optimm molo ratios proviousid 
dotermined for aqueous solutions, excopt that the ferrous ion was added in the form of solid ferrous sulfate. An unusual reaction took place with the peroxide attacking the chlorine on the gamma carton and liberating chlorine gas quito easily at room tomperature. This is perhaps another of the anomalies of the peroxide chemistry. 'fhe solutions were tosted and ne aldehydes were found to have rosulted.

In the general consideration of oxidative methods it was felt desirablo to inrestigato glacial acotic acid as a possible solvent mediun for the oxidation of totramathylenechlorhydrin with potassium dichromate because glacial acetio acid is an excollent solvent for many organio materials and a limited number of inorganic salts. The potassium dichromate wo finoly powdered and dissolved in boiling glacial acotic acid, where it formed a doep red solution. It was found that the potasaium dichromato was soluble in excess of three grams per hundred grams. (CAJTIONll ye attempt has boen made as yot to determine the upper limits of the solubility of potassium dichromate in glacial acetie acid. this oporation may involve explosive hazards.) On addition of an alcohol to the hot dichromato glaoial aootio acid solution, an almost immediato roduction of the dichromato to chromic jons took place, and the solution turned from red to light greon. A series of experiments was carried out to determine the optimum reaction 
temperature and tino(seo Tablo 6 and 7). The yields based on tetramethylenechlorhydrin wore highly satisfactory, being $63.5 \%$ under optimum conditions. The dichromate oxidation method was then applied to rarious arailablo alcohols that were considered representative types. These yields were also highly satisfactory and compare quito farorably with other published yields. 


\section{STITHESI8}

\section{THE STEPHET REDUCTION OF MITRIIES}

The Stophen Roduction was carried out in the following manor: Constant boiling hydrobromio aoid wis reaoted with trimothylenechlorhydrin to give trimethylenechlorobromide. Then the trimethylenochlorobromide reacted with potassium oyanide to gite gama-ohlorobutyronitrile. The latter was roacted with anhydrous stannous chloride to giro the ininostamichloride addition product, which wa decomposed in water.

Proparation of Constant Boiling Hydrobromic Aoid

One pound of hydrobromio acid (34\%, 131 Sp. Gr.) was distilled until the boiling point reached $126^{\circ} \mathrm{C}$. The resulting constant bolling solution gave the following: $1.49 \mathrm{Sp}$. Gr., 47.8\% hydrobromie acid.

Synthesis of Trinethylonechlorobromide (1)

One and a half moles of trimothylenechlorhydrin was treated with three moles of hydrobromic aoid (47.8\%), and three moles of sulfuric acid was added gradually. The mixture was 
rofluxed for one hour and distilled until no water insoluble product appeared. The water insolublo layor was separated and washed with water, thon with $50 \mathrm{~g}$ of cold concentrated sulfuric acid, and finally with sodium oarbonate $(50 \mathrm{~g}$ in 50000 of mater). The rosulting compound was separated, dried with $10 \mathrm{~g}$ coloim ohloride, and distilled.

Data

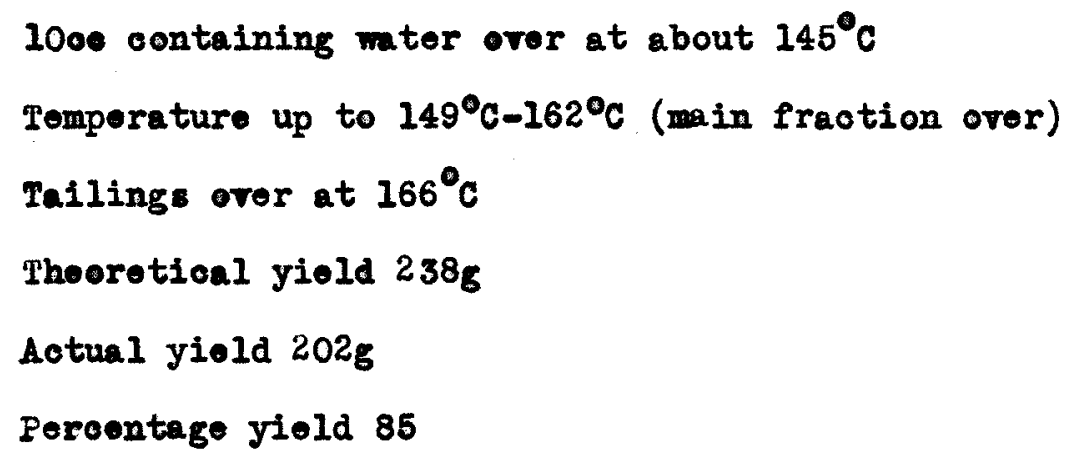

To ono mole of hydratod stannous ohloride two moles of aootic anhydride was addod cautiously since much heat was orolred. The resulting salt was washod froe of acotio acid and excess aoetio anhydride with dry othor and proserved in a dessicator. Preparation of Game-Chlorobutyronitrile 1.2 moles of potassium cyanide and $126 \mathrm{co}$ of water were put in a round bottom flask and warmed with stirring until dissolred. To this mixture was addod 49200 thyl alcohol and 
1.4 moles of trimethylenechlorobromide and refluxed one and a half hours. 63000 of weter was added, and the gamachlorobutyronitrile was collected in 112 co of ohlorororm and removed from the aqueous solution. The ohloroform solution was washed with 200 ce calcium chloride solution $(1+1$ of saturated calcium chloride and water). The solution was dried over fused caloium chloride and distilled in a modified olaisen flask until the temperature roached $120^{\circ} \mathrm{C}$. The resulting product was fraotionated.

Data

$\begin{array}{lll}40^{\circ}-80^{\circ} & 25 \mathrm{~mm} & \text { First fraction } \\ 84^{\circ}-92^{\circ} & 28 \mathrm{~mm} & \text { Main fraction } \\ 97^{\circ}-107^{\circ} & 19 \mathrm{~mm} & \text { Tailings }\end{array}$

Percentage yield 26

Reduction of Aldimino Stannichloride of Gamma-Chlorobutyronitrile

One and one-half moles of anhydrous stannous chloride was added to dry ethor, forming a susponsion. The susponsion was saturatod with dry hydrogen ohloride until two layors formed, and the nitrile was then added. The hydrogen chloride was proparod by adding concentrated sulfuric acid to sodium chloride and sorubbing the gas with concentrated sulfuric acid. The reoction failod to give an addition product immediately. Howerer, after sixteen hours refluxing, a white oily emulsion appoared at the interface of the two layers. The emulsion broke up on addition of oold 
wator. The otherial solution had a characteristic odor resembling an ester. A light blue color dereloped with fuohin aldehydo reagent after standing several hours. Tests with Fehling Solution wore inconclusive. A sodium. bisulfite addition product was attempted, at the some time running a semple of normal butyraldehyde as a control. No addition produts were formed. The absence of the erystalline aldiminestanniohloride and the failure of a definitely positive aldehyde test to be obtained made it nooessary to make a second run, verying the experimental conditions.

Bun two was op similar to the first but s rofluxed for eighty-four hours and allowed to stand two wooks at room temperature. A small quantity of white solid appeared at the interface of the two liquids. This solid was inoreased by the addition of a drop of water, which was added following Whitmoro's lino of reasoning (12). The solid which separated out was dissolred in water. Tho filtrate oraporated free of ether and exoess hydrogen ohloride, then extrected with other to recover the unreacted nitrile and any aldehyde that might have been formod in the solution due to hydrolysis. The mixture was racuum fractionatod and yielded no satisfactory indication of aldehyde. 


\section{OXIDATION YGTHODS}

The oxidation methods were carried out on tetramothyloneohlorhydrin, which was derived from totrahydrofuran. The four methods omployed used pure oxygen and a catalyst, air and a catalyst, hydrogen peroxide, and finally potassium diehromate.

Proparation of Totramethylenechlorhydrin

Dry hydrogen chloride produced from sodium chloride and concentrated sulfuric acid and sorubbed through concentrated sulfuric acid was run into $100.8 \mathrm{~g}$ tetrahydrofuran and cooled in an ice bath until the solution was satursted. The mixture was put under reflux until the temperature of the solution reached $93^{\circ} \mathrm{C}$. This reaction required on overall time of six hours. The solution was distilled at atmospheric pressure until it was froed of totrahydrofuran. Tho romaining liquid was fractionated at $14 \mathrm{~mm}$, and the fraction coming over at $81^{\circ}-83^{\circ} \mathrm{C}$ rotained.

Data

$$
\begin{array}{lr}
\text { Theoretical yield } & 152 \mathrm{~g} \\
\text { Actual yiold } & 66.8 \mathrm{~g} \\
\hline \text { Porcontage yield } & 44
\end{array}
$$


Oxidation by Moans of Pure Oxygen

Five grams of totrahydrofuran and one gram of actirated charcoel wero added to 10000 carbontetrachlorido, and oxygon was bubbled through a capillary tube into the solution for six hours. The solution was tested for aldohydes with negative rosults.

Oxidation by Means of Copper Bronze Cetalyst

Iwo grams of tetramothyloneohlorhydrin, $1.8 \mathrm{~g}$ quinoling, $2 \mathrm{~g}$ meta-dinitrobenzene, $0.5 \mathrm{~g}$ copper bronze, $10 \mathrm{~g} 4,4$-dichlordiphenyl were put into a 10000 distilling flask equippod with a bubbler and connected to the racuum line. The flask placed in an oil bath and the temperature raised to $150^{\circ} \mathrm{C}$. Imnodiately totrahydrofuran began distilling over. The method was considered useless for the compound desired and was abandoned.

Oxidation with Hydrogen Feroxide

Iwo grams of ferrous sulfato was dissolved in as little water as possible by heating and then put into a round bottom flask. $20 \mathrm{~g}$ of tetramethyleneohlorhydrin weighed into the flask and 2000 of water added. 15400 of $6 \%$ hydrogen peroxide derived from $29 \%$ superoxol was added from a dropping funnel. 
The temperature wont up rapidly to $35^{\circ} \mathrm{C}$ on the addition of the first hydregen peroxide. The reaction mixture was coolod by imorsing in a water bath. 1 light rod color appeared in the solution. After vigorous stirring of sovoral hours, almost all the elcohol was in solution except a little around the surface perimeter, where it had a polymorio appoaranoo. A ponetrating characteristio odor noted soon after the first addition of hydrogen peroxide. After all the hydrogen peroxide nes added, the mixture was stirred rigonously and allowed to stand overnight at room tomperature. After 48 hours the mixture had lost its red oolor but had retained an aldehyde odor. The solution was acid to mothyl me. The aqueous solution was extracted with othor. No aldehyde s recovered. Further study of the hydrogen peroxide oxidation was mado, usinf forrous sulfate as oatalyst. A sories of samplos was run to establish the optimum conditions for the reaction, rarying temperature and the mole ratios of forrous ion, aloohol, and hydrogen peroxide. The reactions wore carried out in a borate tosting tube, using a mochanical stirrer with a glass rod as agitator. The aloohol and ferrous ion in the form of a ferrous ammonium sulfate solution were addod from Mohr pipettes in the desired molo ratios and the hydrogen peroxide slowly added to the mixture boing agitated. The reaction timo was arbitrarily 
sot at twenty minutos.

The aldehyde solutions resulting from the various exidations were made up to 80000 with isopropyl alcohol. A suitable aliquot s chosen and added to 20000 of a saturated solution of 2,4-dinitrophenylhydrazpo in 2 molar hydrochlorio acid. 20000 of 2 molar hydrochloric acid was added, and the solutions were allowed to digost a minimum of two hours. The resulting prooipitates wor oollooted in tarod Goooh orucibles and washed twice with 2 molar hydrochloric acid and with distilled water until free of chloride. The preoipitates were then dried for two hours at $100^{\circ} \mathrm{C}$, cooled, and woighed.

\section{TABLE I}

Effect of Reaction Temperature on Yield, Using Superoxol

\begin{tabular}{ccccc}
\hline Temperature & Moles ROH & Moles Fett & Moles $\mathrm{K}_{2} \mathrm{O}_{2}$ & $\begin{array}{c}\text { Yield (Based } \\
\left.\text { on } \mathrm{H}_{2} \mathrm{O}_{2}\right)\end{array}$ \\
\hline $10^{\circ} \mathrm{C}$ & .00690 & .000940 & .00320 & $0 \%$ \\
$25^{\circ} \mathrm{C}$ & .00690 & .000940 & .00190 & $27.5 \%$ \\
$40^{\circ} \mathrm{C}$ & .00690 & .000940 & .00204 & 24.0 \\
$75 \circ \mathrm{C}$ & .00690 & .000940 & .00208 & $19.5 \%$ \\
$100^{\circ} \mathrm{C}$ & .00690 & .000940 & .00124 & 0
\end{tabular}


TABLE II

Effect of Ratio of Fo/ROH on yield, using $6 \%$ Hydrogen Peroxide and Dostroying Excess $\mathrm{H}_{2} \mathrm{O}_{2}$ with Ferrous Sulfato

\begin{tabular}{|c|c|c|c|c|}
\hline Temperature & Moles ROH & MolesFo & $\mathrm{Moleg} \quad \mathrm{H}_{2} \mathrm{O}_{2}$ & Yiold \\
\hline $\begin{array}{l}30^{\circ} \mathrm{C} \\
30^{\circ} \mathrm{C} \\
30^{\circ} \mathrm{C} \\
30\end{array}$ & $\begin{array}{l}.0132 \\
.0132 \\
.0132 \\
.0132\end{array}$ & $\begin{array}{l}.00152 \\
.000760 \\
.000504 \\
\text { zone }\end{array}$ & $\begin{array}{l}.00380 \\
.00380 \\
.00380 \\
.00380\end{array}$ & $\begin{array}{l}19.1 \% \\
17.8 \% \\
19.3 \% \\
19.6 \%\end{array}$ \\
\hline
\end{tabular}

\section{TABLE III}

Effect of Ratio of $\mathrm{Fe} / \mathrm{ROH}$ on yield, using Mangane se Dioxide to Destroy Excess Peroxide

\begin{tabular}{lllll}
\hline Temperature & Moles ROH & Moles Fe ${ }^{++}$Moles $\mathrm{H}_{2} \mathrm{O}_{2}$ & Yield \\
\hline $30^{\circ} \mathrm{C}$ & .0132 & .00152 & .00380 & $28.0 \%$ \\
$30^{\circ} \mathrm{C}$ & .0132 & .00076 & .00380 & $22.8 \%$ \\
$30^{\circ} \mathrm{C}$ & .0132 & .000504 & .00380 & $18.6 \%$ \\
$30^{\circ} \mathrm{C}$ & .0132 & .000260 & .00380 & $5.2 \%$ \\
$30^{\circ \mathrm{C}}$ & .0132 & None & .00380 & None \\
\hline
\end{tabular}


TABLE IV

Effect of Mole Ratio of $\mathrm{H}_{2} \mathrm{O}_{2}$, Using Manganese Dioxido to Destroy the Exeess Hydrogon Peroxide

\begin{tabular}{lllll}
\hline Temperature Moles ROH & Moles Fe ${ }^{++}$ & Moles $\mathrm{H}_{2} \mathrm{O}_{2}$ & Yield \\
& & & & \\
\hline $30^{\circ} \mathrm{C}$ & .0132 & .000940 & .00152 & none \\
$30^{\circ} \mathrm{C}$ & .0132 & .000940 & .00750 & $16.2 \%$ \\
$30^{\circ} \mathrm{C}$ & .0132 & .000940 & .00990 & $12.3 \%$ \\
$30^{\circ} \mathrm{C}$ & .0132 & .000940 & .00380 & $28.0 \%$ \\
\hline
\end{tabular}

\section{TABLE V}

Determination of Degree of Aldehyde Formations in Glacial Acetic Acid, Using superoxol

\begin{tabular}{|c|c|c|c|c|}
\hline Temperature & Molos ROH & Moles Fot+ & Moles $\mathrm{H}_{2} \mathrm{O}_{2}$ & Yield \\
\hline $30^{\circ} \mathrm{C}$ & .0132 & $\begin{array}{l}\text { Saturated } \\
\text { solution }\end{array}$ & & none \\
\hline 30 & .0132 & $\begin{array}{l}\text { Presence of } \\
\text { solid } \mathrm{FeSO}_{4}\end{array}$ & .0264 & none \\
\hline
\end{tabular}

Potassium Dichropato Oxidation

Potassium dichromato was dissolrod in boiling glacial acotio acid and used as on oxidizing agent for the proparetion 
of gama-ohlorbutryaldehyde and rarious other higher aldehydos. The oxidizing mixtures were made by dissolving one gram of powdered potassiun diohromate in 5000 of boiling acid.

\section{TABLE VI}

Effect of Rootion Temperature

\begin{tabular}{llllll}
\hline Time Yoles ROH & Moles $\mathrm{K}_{2} \mathrm{Cr}_{2} \mathrm{O}_{7}$ & Temporature & $\begin{array}{l}\text { Acetic } \\
\text { acid }\end{array}$ & Yield \\
3 min. .0100 & .00340 & $105^{\circ} \mathrm{C}$ & 5000 & $60 \%$ \\
3 min. .0100 & .00340 & $95 \% \mathrm{C}$ & 5000 & $57.5 \%$ \\
3 min. .0100 & .00340 & $85^{\circ} \mathrm{C}$ & 5000 & $49 \%$ \\
\hline
\end{tabular}

TABLE VII

Effoct of Renction Timo

\begin{tabular}{rrrrr}
\hline Time Moles ROE & Moles $\mathrm{K}_{2} \mathrm{Cr}_{2} \mathrm{O}_{7}$ & Temperature & $\begin{array}{l}\text { Acotio } \\
\text { 20id }\end{array}$ & Yiold \\
$3 \mathrm{~min} . .0100$ & .00340 & $105^{\circ} \mathrm{C}$ & 5000 & $60 \%$ \\
$8 \mathrm{~min}, .0100$ & .00340 & $105^{\circ} \mathrm{C}$ & 5000 & $63.5 \%$ \\
$15 \mathrm{~min}, .0100$ & .00340 & $1050 \mathrm{C}$ & 5000 & $61.0 \%$ \\
$30 \mathrm{hrs} . .0100$ & .00340 & $300 \mathrm{C}$ & 5000 & $13.9 \%$ \\
\hline
\end{tabular}




\section{TABLE VIII}

Determination of Aldehydes Formod From Various Alcohols, Using the Potassium Dichromato Acetic Acid Procedure

\begin{tabular}{llllll}
\hline Timo Moles ROH Moles $\mathrm{K}_{2} \mathrm{Cr}_{2} \mathrm{O}_{7} \quad$ Temperature & $\begin{array}{l}\text { Acetic } \\
\text { Qcid }\end{array}$ & Yield \\
3 min. .0100 & .00340 & $\frac{\text { Allyl Alcohol }}{105^{\circ} \mathrm{C}}$ & 5000 & $102 \%$ \\
3 min. .0100 & .00340 & $\frac{\text { Benzyl Alcohol }}{105^{\circ} \mathrm{C}}$ & 5000 & $86 \%$ \\
3 min. & .0100 & .00340 & $\frac{2-\text { Ethylhexanol }}{105^{\circ} \mathrm{C}}$ & 5000 & $68 \%$ \\
3 min. & .0100 & .00340 & $\frac{\text { Amyl Alcohol }}{105^{\circ} \mathrm{C}}$ & 5000 & $65 \%$ \\
\hline
\end{tabular}


S U Y Y $\triangle R Y$

A study has been made of various possible mothods of syathesizing gama-ohlorobutyraldehydo. The Stephen Reaction under normal conditions has been found unsuitable for the synthesis but giving indications of a possiblo farorable reaction at higher tomperatures. Oxidation mothods have beon invostigated and the optimum roaction oondition esthblishod for the use of potassium dichromate and hydrogen poroxide as axidizing agents. Camma-ohlorbutyraldehyde has been synthesized by two mothods not hitherto reported. A now tochnique has beon devoloped for the preparation of aldehydos. The yields by this now method on semples of ropresentative alcohols have been found to vary from 63 to 100 per oont. 
LITERATURE CITED

1 - Conant, Organic Synthesis, 8, 58 (1929)

2 - Goldschmidt, Bor., 61, 223-233 (1928)

3 - Hart, Ind. Eng. Chom., Anal. Ed., 11102 (1939)

4 - Hixon, J. Am., Chem. Soo., 561595 (1934)

5 - Kharasch, J. Am. Chem. Soo. 552468 (1933)

6 - King, J. Chom, Soc., 352 (1936)

7 - Mayo, Chom. Rev•, 27, 351 (1940)

8 - Mellor, 1 Comprohonsive Troatiso on Inorganio And Theoretical Chemistry, Vol. I, p. 944, How York, Longmans, Groenand Co.

9 - Paul, Comptes Rendus 215, 303 (1942)

10 - Paul, Comptes Rendus 211645 (1940)

11 - Stophon, J. Chom. Soc., 1271874 (1925)

12 - Whitmore, Organic Chomistry, p.248, Now York, D. Van Nostrand Co., 1934

13 - Mitmoro, Organic Chomistry, p.791, Now York, Van Nostrand Co., 1934

14 - Whitwore, Organic Chemistry, p.233, New York, D. Nostrand Co., 1934

15 - Witzoman, J. Am. Chem. Soc., 36 2287 (1914)

16 - Zotzsche, Ber., 542037 (1921) 